\title{
Adolescents and Their Teenage Brains
}

\author{
David Moshman \\ Educational Psychology, University of Nebraska, Lincoln, Nebr., USA
}

In 1991, I presented a paper on the rationality and maturity of adolescents at the biennial meeting of the Society for Research in Child Development in Seattle, Wash., USA. In the audience was Deanna Kuhn, then editor of this journal, who invited me to send her a manuscript based on my talk for publication in Human Development. The resulting article, 'Adolescent reasoning and adolescent rights' [Moshman, 1993], reviewed psychological research demonstrating that adolescents are distinct from children but not from adults in reasoning and decision making.

In 2011, I posted on my Huffington Post blog a brief analysis debunking five myths about teenage brains [Moshman, 2011b]. In a modern counterpart to presenting a paper, I emailed the link to several dozen developmentalists I thought might be interested. I immediately received an invitation from Larry Nucci, current editor of Human Development, to send him an adapted version for this Editor's Corner.

What has happened since 1991? Psychological research in the past two decades has continued to support my earlier conclusion that adolescents are qualitatively distinct from children but not from adults [Moshman, 2011a]. But enduring conceptions of irrational adolescents will not allow us to accept this.

The past two decades, for a variety of reasons, have seen a dramatic rise in research on adolescent brains [Casey, Getz, \& Galvan, 2008; Spear, 2010]. Such research is important, of course, but much of it seems aimed at documenting adolescent immaturity and irrationality right in the brain itself. Sidestepping psychological research on behavior and cognition, brain science attributes vaguely conceptualized social phenomena to whatever statistical patterns and age-related trends in neuroprocessing can be detected.

Consider 'adolescent risk taking.' The term is so common and seemingly natural that we think we know what it means. But do we? Psychological research does not support the proposition that risk taking is a special phenomenon of adolescence. We all take risks, and often we are right to do so. There is, to my knowledge, no standard of reasonable risk taking that is met by most or all adults but few adolescents. Any theory of the adolescent brain that purports to explain why adolescents are categorically distinct in their risk taking is explaining a phenomenon that does not exist.

Contemporary thinking about adolescents is nicely illustrated by a 2006 cartoon in The New Yorker [Steinberg, 2009], which shows parents ordering their ado-

\begin{tabular}{ll}
\hline KARGER & ( 2011 S. Karger AG, Basel \\
Fax +41 61 306 12 34 & 0018-716X/11/0544-0201\$38.00/0 \\
$\begin{array}{l}\text { E-Mail karger@karger.ch } \\
\text { www.karger.com }\end{array}$ & $\begin{array}{l}\text { Accessible online at: } \\
\text { www.karger.com/hde }\end{array}$
\end{tabular}

David Moshman

Educational Psychology, 114 Teachers College Hall University of Nebraska

Lincoln, NE 68588-0345 (USA)

E-Maildmoshman1@unl.edu 
lescent son to go to his room until his cerebral cortex matures. The cartoon illustrates at least five assumptions about adolescents and their brains: (1) adolescents are categorically different from adults; (2) adolescents are less rational than adults; (3) adolescent cognition and behavior are explained by their teenage brains; (4) adolescent brain development is a maturational process directed by genes; and (5) the outcome of that process is a state of maturity achieved in adulthood.

All of these assumptions are false. Let me be clear: I am not just saying we do not have sufficient evidence to support some of these claims. We have plenty of evidence with regard to all of them. My point is that the evidence shows them all to be false [Moshman, 2011a].

First, adolescents are a distinct group with respect to children but not with respect to adults. Even among young teens we readily observe forms and levels of knowledge and reasoning that are rarely seen in children under the age of 10 or 11. Development beyond childhood, however, is highly variable in direction and extent. There are, to my knowledge, no forms or levels of knowledge, reasoning, or psychological functioning that are common in adults but rare among adolescents.

Second, research in cognitive psychology since the 1970s shows that we are all irrational much of the time. Even as we develop rational competencies, our reasoning and behavior are subject to many forces and constraints that limit the application of those competencies. In addition to risk taking, adolescents are specifically accused of egocentrism, impulsivity, peer conformity, and present (over future) orientation. They are guilty as charged, to varying degrees, but adults of all ages show all the same tendencies, not all of which are always bad. Individual differences beyond age 12-14 are not strongly related to age. By any measure, many 14 -year-olds function beyond the level of many 40 -year-olds.

Third, we are very far from reducing psychology to biology, if indeed this can be done. We cannot predict or understand how adolescents perceive, infer, think, feel, act, reason, or reflect by examining their brains. Our rich knowledge of adolescent functioning is, and will continue to be, the result of decades of psychological research on their cognition and behavior. Brain research is crucial for a full picture but it cannot replace psychological research and does not provide an ultimate explanation.

Fourth, genes do not cause brain development. Genes are the outcome of an evolutionary process and the origin of a developmental process. The brain, however, is part of a dynamic system that includes an active organism interacting with an active environment. Its development is intricately intertwined with the development of that system, which is a function of the system's ongoing actions and interactions. Brain development is as much the result of cognitive activity as its cause. It is not a gene-directed process of age-related maturation.

Finally, we adults (including we developmentalists) are enthralled by mythic conceptions of a maturity we have attained that adolescents have yet to reach. We're right to think that we are more mature than children. But adolescents are also more mature than children, and not so different from us with respect to their brains, cognition, and behavior. For most of human history, persons in their teens were deemed adults - not 'adolescents' or 'teenagers' - and were expected to work, marry, have children, run a household, and engage in other adult tasks and roles associated with their gender and status. Many adolescents are still developing, but so are many adults. Adolescents are, literally, young adults. 
There is nothing special about teenage brains. Claims about the relative size and merit of the brains of various sorts of people have long provided a pseudoscientific basis for oppression of women, racial minorities, and others with brains deemed inferior. The case against teen brains is no stronger. Close enough scrutiny with modern techniques allows us to identify statistically detectable differences across the brains of whatever individuals or groups we choose to study, but leaping from there to categorical claims about the cognition or behavior of various groups is a matter of ideology, not science. This may seem less objectionable in the case of adolescents but it is no more scientific.

Cognitive development often continues long beyond childhood, especially in cognitively rich and challenging environments that encourage active engagement and reflection. There is nothing about teen brains, however, to justify distinguishing adolescents from adults. We should study development when it occurs and promote it when we can, but beyond about age 12 we should not expect that knowing a person's age will enlighten us about his or her reasoning, rationality, or psychological functioning. Nothing about brain science changes that.

As for the adolescent in The New Yorker cartoon, I don't know what he did or what his parents should do. Whatever the problem, however, waiting for his brain to grow up is surely not the solution.

\section{References}

Casey, B.J., Getz, S., \& Galvan, A. (2008). The adolescent brain. Developmental Review, 28, 62-77.

Moshman, D. (1993). Adolescent reasoning and adolescent rights. Human Development, 36, 27-40.

Moshman, D. (2011a). Adolescent rationality and development: Cognition, morality, and identity (3rd ed.). New York: Psychology Press.

Moshman, D. (2011b, May 17). The teenage brain: Debunking the 5 biggest myths. Huffington Post. http://www.huffingtonpost.com/david-moshman/adolescents-and-their-tee_b_858360.html.

Spear, L. (2010). The behavioral neuroscience of adolescence. New York: Norton.

Steinberg, L. (2009). Should the science of adolescent brain development inform public policy? American Psychologist, 64, 739-750. 